\title{
SELECTIVITY OF FLUAZIFOP-P-BUTYL IN YOUNG COFFEE PLANTS
}

\author{
Giovani Belutti Voltolini ${ }^{1}$, Dalyse Toledo Castanheira ${ }^{2}$, Pedro Menicucci Netto ${ }^{3}$, \\ Ademilson de Oliveira Alecrim ${ }^{4}$ Tiago Teruel Rezende ${ }^{5}$, Rubens José Guimarães ${ }^{6}$, \\ Adenilson Henrique Gonçalves ${ }^{7}$
}

(Received: April 09, 2019; accepted: June 05, 2019)

\begin{abstract}
Weed control is fundamental in coffee cultivation due to their big interference, competing with the crop for water, light and nutrients. Among the control methods used, chemical control is highlighted, as a function of its high efficiency and low cost. However, due to application failures, herbicide drift phytotoxicity is common. Aiming at the search for selective active ingredients in coffee plants, the objective in this study was to evaluate the selectivity of the active ingredient Fluazifopp-butyl on the young coffee plants, and its effects on plant morphology, anatomy and physiology. The experiment was carried out in a greenhouse, with 'Topázio MG 1190' coffee plants (Coffea arabica L.), cultivated in pots with a capacity of 11 L substrate. The statistical design was randomized block design (RBD), with four replications and four doses of the herbicide, making up 16 experimental plots. Each plot consisted of three plants. The treatments were: $0 \% ; 50 \% ; 100 \%$ and $200 \%$ of the recommended commercial dose of the herbicide Fluazifop-p-butyl. The evaluations were performed at 120 days after application of the treatments. Morphological, physiological and anatomical characteristics were evaluated. Regardless of the evaluated characteristic, there was no difference between the doses of the herbicide. There were no visual phytotoxicity symptoms in the young coffee plants that received the herbicide Fluazifop-p-butyl. The growth of the coffee plants and the physiological and anatomical characteristics were not altered due to the application of the herbicide Fluazifop-p-butyl.
\end{abstract}

Index terms: Coffea arabica L., herbicide, drift.

\section{SELETIVIDADE DE FLUAZIFOP P BUTYL EM CAFEEIROS JOVENS}

RESUMO: Controle de plantas daninhas é fundamental na cafeicultura devido à grande interferência que estas exercem, competindo com a cultura por água, luz e nutrientes. Dentre os métodos de controle utilizados destaca-se o controle químico, por sua alta eficiência e baixo custo. Contudo, devido a falhas na aplicação, são frequentes casos de fitotoxicidade pela deriva dos herbicidas. Visando a busca por ingredientes ativos seletivos ao cafeeiro, objetivou-se avaliar a seletividade do ingrediente ativo Fluazifop p butyl em plantas jovens de cafeeiros, e seus efeitos na morfologia, anatomia e fisiologia das plantas. O experimento foi realizado em casa de vegetação, com plantas de cafeeiro (Coffea arabica L.) da cultivar Topázio MG 1190 , cultivadas em vasos com capacidade de 11 litros de substrato. O delineamento estatístico utilizado foi o DBC, com quatro repetições e quatro doses do herbicida, perfazendo, 16 parcelas experimentais. Cada parcela foi composta por três plantas. Os tratamentos foram: $0 \% ; 50 \% ; 100 \%$ e $200 \%$ da dose comercial recomendada do herbicida Fluazifop p butyl. As avaliações foram realizadas aos 120 dias após a aplicação dos tratamentos. Foram avaliadas características morfológicas, fisiológicas e anatômicas. Independentemente da característica avaliada não houve diferença entre as doses do herbicida. Não ocorreram sintomas de fitotoxicidade visuais nos cafeeiros jovens que receberam o herbicida Fluazifop p butyl. O crescimento das plantas de café e as características fisiológicas e anatômicas não foram alterados em função da aplicação do herbicida Fluazifop p butyl.

Termos para indexação: Coffea arabica L., herbicidas, deriva.

\section{INTRODUCTION}

Brazilian coffee production has great socioeconomic importance, with millions of jobs being generated directly and indirectly in the production chain, thus providing income for a large number of people. Of the total coffee produced in the world, about $30 \%$ is from Brazil (International Coffee Organization, 2017).

However, the productivity of the national coffee-growing area is still low, at around 30,74 sacks per hectare (Conab, 2018), a number well below comparing the potential of young plantations, in addition to other factors, there are still old and depleted tillage, needing renovation.

Thus, the yield of each field in a coffee plantation is directly related to factors that may make it difficult to manage or even make the venture unfeasible. Among these factors, it is possible to highlight: soil fertility, nutritional status of plants, phytosanitary control, use of application technologies, climatic conditions and weed management (Oliveira, et al., 2013).

\footnotetext{
1,3,4,6,7 Universidade Federal de Lavras/UFLA - Departamento de Agricultura/DAG - Cx. P. 3037 - 37.200-000 - Lavras - MG giovanibelutti77@hotmail.com, pedromenicucci2010@hotmail.com, ademilsonagronomia@gmail.com,rubensjg@dag.ufla.br, adenilsonhg@dag.ufla.br.

${ }^{2}$ Universidade Federal de Viçosa - UFV- Departamento de Fitotecnia/ DFT - Avenida Peter Henry Rolfs, s/n Campus Universitário 36.570-900 - Viçosa - MG - dalysecastanheira@hotmail.com

${ }^{5}$ Universidade José do Rosário Vellano - Rodovia MG 179, Km 0 - Campus Universitário - 37.152- 440 - Alfenas - MG tiago.rezende@unifenas.br
} 
In this context, weed management is of great importance for the success in the cultivation of this crop, once they compete with the coffee plant for elements essential to its development, such as water, light, space and nutrients (Fialho, et al., 2011; Lorenzi, 2014).

Among the control methods used, chemical control is highlighted due to the advantages it has in relation to the others. However, there is a lack of selective herbicides to the coffee plant that have registration for the crop. Thus, coffee farmers use non-selective herbicides, in a directed jet, costing the application and still taking great risks of drift, causing damage to the plants (Silva et al. 2017). This damage, which affects plant growth and development, can be avoided opting selective herbicides to coffee, which could be applied in the total area with significant savings in production costs.

There are few herbicides recommended for coffee plants with selective action (Lorenzi, 2014) and, in many cases, the adoption of nonselective herbicides implies damaging the plants due to their phytotoxicity, as observed in the study conducted by Silva et al. (2017), in which they used PROTOX inhibitors in young coffee plants. However, this damage occurs in the field due to the use of incorrect application technology with consequent drift at the time of application (Gandolfo, et al., 2014).

Among these herbicides that may be selective to the crop, the herbicide Fluazifopp-butyl, which is widely used for the control of poaceae in agriculture, can be highlighted, and its use has been intensified as an alternative to the control of weeds resistant to the herbicide Glyphosate (Rodrigues e Almeida, 2018).

This herbicide has as its mechanism of action the inhibition of the enzyme Acetyl CoA carboxylase, within the chemical group of aryloxyphenoxy propionate herbicides. The inhibition of ACCase perfectly explains the reduction in growth, the increase in membrane permeability and the ultrastructural effects observed in cells. This enzyme, found in the plastid stroma, converts Acetyl Coenzyme A (AcetylCoA) into Malonyl Coenzyme A (Malonyl-CoA) by the addition of a $\mathrm{CO}_{2}$ molecule to AcetylCoA. It is a key reaction at the beginning of lipid biosynthesis that measures the rhythm of this biosynthesis (Burke, et al., 2006).

Therefore, the possibility of using this herbicide with selectivity to coffee seedlings emerges as a hypothesis to reduce the cases of phytotoxicity in coffee growing areas. In this context, was to evaluate the selectivity of the active ingredient Fluazifop-p-butyl in young coffee plants.

\section{MATERIAL AND METHODS}

The experiment was carried out in a greenhouse in the municipality of Lavras-MG, located in the southern region of the state of Minas Gerais, at altitude of $918 \mathrm{~m}, 21^{\circ} 14^{\prime} \mathrm{S}$ latitude and $45^{\circ} 00^{\prime} \mathrm{W}$ longitude, from December 2016 to March 2017. The annual average air temperature is $19.4{ }^{\circ} \mathrm{C}$, with a maximum of $26.1{ }^{\circ} \mathrm{C}$ and the minimum, $14.4{ }^{\circ} \mathrm{C}$.

For the simulation of intoxication, 'Topázio MG1190' coffee (Coffea arabica L.) seedlings were planted in 11-L pots, with 4-5 pairs of leaves. A randomized block design with four replicates and four doses of the herbicide Fluazifop-pbutyl was used: $0 \% ; 50 \% ; 100 \%$ and $200 \%$ of the recommended commercial dose $\left(0.8 \mathrm{~L} \mathrm{ha}^{-1}\right)$ applied directly to coffee plants. Each plot consisted of three plants.

The application of the herbicide at different doses was carried out using a $\mathrm{CO}_{2}$ pressurized costal sprayer, with pressure of 45 pounds, and the spray bar directed close to the top of the plants, with a spray volume of 300 L.ha $^{-1}$. After the application, the plants remained in the greenhouse for 120 days, daily irrigated, aiming at the maintenance of field capacity $(100 \%)$. The conduction and cultural treatment were carried out as recommended by Matiello (2010).

Visual observation and imaging of the symptoms caused by the action of the herbicide were performed daily. The anatomical and physiological evaluations of the plants were performed at the end of the experiment. The following growth characteristics were evaluated: plant height, measured in centimeters from the neck to the terminal bud of the orthotropic branch of plants; number of leaves; stem diameter, measured in millimeters at the collar of the plants; number of plagiotropic branches; leaf area, in $\mathrm{cm}^{2}$, quantified by leaf discs (Cunha et al., 2010); aerial part, root system, plagiotropic branches, ortotropic branche and leaf dry matter, in grams. Root length analysis, in centimeters, was also determined by the sum of the linear extension of each fragment of the root system and the mean root diameter, in centimeters, both using the imaging software Safira (JORGE; SILVA, 2010). 
For the evaluation of leaf anatomy, at 104 days, leaves located between the second and third node of the plagiotropic branch of the plants were collected. Subsequently, in the laboratory, the paradermic and transverse sections were performed. Those paradermic were obtained before of collection, using the universal instant adhesive (cyanoacrylate ester) method (SEGATTO et al., 2004). In order to obtain the cross sections, the plant material underwent dehydration in an ethylic series, and then immersed in methacrylate (methodology according to the manufacturer) and sectioned with $0.8 \mu \mathrm{m}$ thickness using a rotary microtome. Subsequently, these were stained with toluidine blue (O'brien; Feder; Mccully, 1964) and the blades were assembled using Entelan ${ }^{\circledR}$ as a medium. The slides of both sections (paradermic and transverse) were observed and photographed under an optical microscope coupled to a digital camera. The images obtained were analyzed in the UTHSCSA-Imagetool program and then the stomatal characteristics, leaf tissues and vascular bundles were evaluated. For the stomatal characterization, the following characteristics were evaluated: stomatal number; polar diameter of the stomata and equatorial diameter of the stomata. Stomatal density (number of stomata per $\mathrm{mm}^{2}$ ) and the polar diameter / equatorial diameters stomatal ratio which is highly correlated with stomatal functionality (Silva, et al., 2014) was calculated using these data. To evaluate leaf tissues, the following were measured: epidermal thickness of the adaxial face; thickness of the palisade parenchyma; thickness of the spongy parenchyma; and thickness of the mesophyll. In the evaluation of vascular bundles, the following parameters were measured: thickness of the phloem region; diameter of xylem vessels; and number of xylem vessels.

For the physiological analyses, a portable infrared gas analysis system (LICOR - 6400XT) was used to evaluate the net photosynthetic rate (A - $\mu \mathrm{mol} \mathrm{CO} 2 \mathrm{~m}^{-2} \mathrm{~s}^{-1}$ ), stomatal conductance (gs $\left.\mathrm{mol} \mathrm{H} 2 \mathrm{O} \mathrm{m}^{-2} \mathrm{~s}^{-1}\right)$, and transpiration rate $(\mathrm{E}-\mathrm{mmol}$ $\mathrm{m}^{-2} \mathrm{~s}^{-1}$ ). The water use efficiency (EiUA - $\mu \mathrm{mol}$ $\mathrm{CO} \mathrm{mmol}^{-1} \mathrm{H} 2 \mathrm{O}$ ), calculated by the $\mathrm{A} / \mathrm{E}$ ratio (Yan et al., 2015) was also evaluated. The evaluations were performed between 9 and 11 o'clock in the morning under artificial light $\left(1000 \mu \mathrm{mol} \mathrm{m}^{-2} \mathrm{~s}^{-1}\right)$, using leaves located between the second and third node of the plagiotropic branch of the plants.

For data analysis, the SISVAR Statistical Software was used (FERREIRA, 2011). The F test was performed, and when in the occurrence of significance, regression and adjustment of the best model was performed.

\section{RESULTS AND DISCUSSION}

According to the visual observation and verification of the obtained images, after 120 days of application of the herbicide Fluazifop-p-butyl, no phytotoxicity symptoms were identified in the coffee plants, pointing to the possible selectivity of the herbicide. The EWRC (1964) scale showed that all plants received score 1, that is it, irrespective of the applied dose of herbicide, there were no visible symptoms in consequence of the application of Fluazifop-p-butyl.

In addition, no differences $(p<0.05)$ were found for any of the evaluated characteristics (Table 1).

According to the obtained results, a selectivity of the herbicide Fluazifop-p-butyl in young coffee plantss is suggested, provided they did not show morphophysiological changes (TABLE 1) in relation to the variation of herbicide doses.

The selectivity of the herbicide in coffee plants can be explained by the fact that eudicotyledons, such as coffee, have two types of the enzyme Acetyl coenzyme A carboxylase (ACCase). The enzyme present in the cytoplasm is equivalent to that of poaceae, but the enzyme in the chloroplasts is insensitive to the action of this herbicide and responds by any lipid synthesis when the cytoplasmic enzyme is inhibited by the product (Sasaki et al., 1995). In the case of poaceae, both enzymes show their cells with only one form of ACCase, both in the cytoplasm and in the stroma of chloroplasts and, therefore, are sensitive to this chemical group.

These results corroborate those found by Yamashita (2009) who, studying the herbicide Haloxifop, belonging to the same chemical group of Fluazifop-p-butyl, observed that coffee plants are tolerant to the applied herbicide. Liu et al. (1993) evaluated the interaction between the herbicide Quizalofop and coffee plants in initial development, and observed a pronounced selectivity of this chemical group to coffee plants. In the same way, Ronchi (2003) used the herbicide Clethodim and observed selectivity of this chemical group to coffee seedlings, thus corroborating the results found in this study.

Carvalho et al. (2014) studied the herbicide Fluazifop-p-butyl in coffee seedlings with and without inoculation of arbuscular mycorrhizal fungi, and observed 'Catuaí IAC 99' selectivity at the herbicide package-insert dose. However, the same authors observed that, when mixed with the herbicide Fomesafen, there are growth losses in coffee plants. 
TABLE 1 - Height (HGT), collar diameter (CDM), number of plagiotropic branches (NPB), length of plagiotropic branches (LPB), number of leaves(NOL), dry matter of the orthotropic branch (DMOB), dry matter of plagiotropic branches (DMPB), leaf dry matter (LDM), leaf area (LA), root dry matter (RDM), photosynthesis (PSC), stomatal conductance (SC), transpiration (T), biochemical efficiency (BE), root volume (RT), root surface area (RSA), root diameter (RD), total root length (TRL), number of xylem vessels (NXV), diameter of xylem vessels (DXV), phloem thickness (PTN), adaxial epidermis (AED), thickness of palisade parenchyma (TPP), lacunar parenchyma thickness (LPT), abaxial epidermal thickness (AET) and leaf mesophyll thickness (LMT), stomatal number (SN), polar diameter of the stomata (PDS) and equatorial diameter of the stomata (EDS), stomatal density (number of stomata per $\left.\mathrm{mm}^{2}\right)(\mathrm{SD})$ and stomatal functionality (SF), as a function of the variation source (SV) block, dose and residue.

\begin{tabular}{|c|c|c|c|c|c|c|}
\hline \multirow[t]{2}{*}{ SV } & \multirow[t]{2}{*}{$\mathrm{DF}$} & \multicolumn{5}{|c|}{ MS } \\
\hline & & HGT & $\mathrm{CDM}$ & NPB & LPB & NOL \\
\hline Dose & 3 & $31.297^{\mathrm{NS}}$ & $.6857 \mathrm{NS}$ & $1.6875^{\mathrm{NS}}$ & $5.7528^{\mathrm{NS}}$ & $1449.4^{\mathrm{NS}}$ \\
\hline Block & 3 & $269.00^{*}$ & $.5444^{\mathrm{NS}}$ & $6.0764^{*}$ & $49.424^{*}$ & $6551.9 *$ \\
\hline Residue & 41 & 16.108 & 1.7341 & 1.7810 & 17.279 & 648.54 \\
\hline VC (\%) & & 6.21 & 9.68 & 8.00 & 11.63 & 12.11 \\
\hline \multirow[t]{2}{*}{ SV } & \multirow[t]{2}{*}{$\overline{D F}$} & \multicolumn{5}{|c|}{ MS } \\
\hline & & DMOB & DMPB & LDM & LA & RDM \\
\hline Dose & 3 & $8.8503^{\mathrm{NS}}$ & $10.3645^{\mathrm{NS}}$ & $124.481^{\mathrm{NS}}$ & $143045.0^{\mathrm{NS}}$ & $5.6506^{\mathrm{NS}}$ \\
\hline Block & 3 & $63.640^{*}$ & $100.107^{*}$ & $1739.45^{*}$ & $1425218.7^{*}$ & $70.080^{*}$ \\
\hline Residue & 41 & 3.9273 & 10.0661 & 89.5086 & 56267.00 & 12.171 \\
\hline $\mathrm{VC}(\%)$ & & 11.57 & 6.21 & 12.50 & 12.60 & 15.26 \\
\hline \multirow[t]{2}{*}{ SV } & \multirow[t]{2}{*}{$\mathrm{DF}$} & \multicolumn{5}{|c|}{ MS } \\
\hline & & PSC & & $\mathrm{SC}$ & $\mathrm{T}$ & $\mathrm{BE}$ \\
\hline Dose & 3 & $2.1265^{\mathrm{NS}}$ & \multicolumn{2}{|c|}{$0.00001^{\mathrm{NS}}$} & $823.181^{\mathrm{NS}}$ & $0.0496^{\mathrm{NS}}$ \\
\hline Block & 3 & $6.3918^{*}$ & & $0.00176^{*}$ & $49065.4^{*}$ & $0.2639^{*}$ \\
\hline Residue & 41 & 1.7292 & & 0.00014 & 942.032 & 0.0377 \\
\hline VC (\%) & & 35.50 & & 31.06 & 13.81 & 28.68 \\
\hline SV & $\mathrm{DF}$ & & & MS & & \\
\hline & & RT & & SA & $\mathrm{RD}$ & TRL \\
\hline Dose & 3 & $6.1028 \times 10^{9} \mathrm{NS}$ & 4.680 & $\times 10^{9 \mathrm{NS}}$ & $0212^{\mathrm{NS}}$ & $350313,6^{\mathrm{NS}}$ \\
\hline Block & 3 & $4.7155 \times 10^{9} \mathrm{NS}$ & $1.025^{\prime}$ & $\mathrm{x} 10^{10 \mathrm{NS}}$ & $0151^{\mathrm{NS}}$ & $5105359,0^{\mathrm{NS}}$ \\
\hline Residue & 41 & $3.7849 \times 10^{9}$ & 6.53 & $1 \times 10^{9}$ & 0.0212 & 9009194,1 \\
\hline $\mathrm{VC}(\%)$ & & 27.16 & & .52 & 6.96 & 22.00 \\
\hline SV & DF & & & MS & & \\
\hline & & NXV & & DXV & PTN & AED \\
\hline Dose & 3 & $12.5764^{\mathrm{NS}}$ & & $0,9474^{\mathrm{NS}}$ & $3,2221^{\mathrm{NS}}$ & $0,7515^{\mathrm{NS}}$ \\
\hline Block & 3 & $96,7430^{\mathrm{NS}}$ & & 3,3679 NS & $5,3942 \mathrm{NS}$ & $2,2950^{\mathrm{NS}}$ \\
\hline Residue & 41 & 107,6672 & & 2,2774 & 7,8305 & 0,3654 \\
\hline $\mathrm{VC}(\%)$ & & 5,44 & & 14,19 & 8,76 & 4,83 \\
\hline SV & DF & & & MS & & \\
\hline & & TPP & & PT & AET & LMT \\
\hline Dose & 3 & $6,3934^{\mathrm{NS}}$ & 91 , & $297^{\mathrm{NS}}$ &, $5657^{\mathrm{NS}}$ & $84,9422^{\mathrm{NS}}$ \\
\hline Block & 3 & $6,7571^{\mathrm{NS}}$ & 41 , & $031^{\mathrm{NS}}$ &, $0699 \mathrm{NS}$ & 9,9503 NS \\
\hline Residue & 41 & 3,2917 & & 5612 & 0,3022 & 46,8625 \\
\hline VC (\%) & & 5,71 & &, 05 & 5,90 & 5,16 \\
\hline SV & $\mathrm{DF}$ & & & MS & & \\
\hline & & $\mathrm{SN}$ & PDS & EDS & SD & SF \\
\hline Dose & 3 & $3,1875 \mathrm{NS}$ & $0,3476^{\mathrm{N}}$ & $0,1785^{\mathrm{NS}}$ & $468,24 \mathrm{NS}$ & $0,0073 \mathrm{NS}$ \\
\hline Block & 3 & $2,8542 \mathrm{NS}$ & $0,0742^{N}$ & $0,0553 \mathrm{NS}$ & $422,24 \mathrm{NS}$ & $0,0029 \mathrm{NS}$ \\
\hline Residue & 41 & 4,4599 & 0,2172 & 0,1568 & 648,44 & 0,0059 \\
\hline VC (\%) & & 5,81 & 2,97 & 3,82 & 5,77 & 5,09 \\
\hline
\end{tabular}

NS: not significant by the $\mathrm{F}$ test, at $5 \%$ probability.

DF: degrees of freedom 
It is noteworthy that, even at the dose of $200 \%$ of the commercially recommended for direct application in weeds, considered to be very high and not to be applied in the field, no damage in growth and internal characteristics of coffee plants were observed. Thus, it is safe to emphasize the application of Fluazifop-p-butyl for weed control in coffee plantations in formation, without damage to the crop.

It is important to highlight the importance of this work, because the literature offers scarce studies on the selectivity of herbicides in young coffee plants.

\section{CONCLUSIONS}

There were no visual phytotoxicity symptoms in young coffee plants that received the herbicide Fluazifop-p-butyl.

The growth of coffee plants as well as the physiological and anatomical characteristics were not altered due to the application of the herbicide Fluazifop-p-butyl.

The herbicide Fluazifop-p-butyl can be used to control weeds in young coffee plantations, including in the total area, selectively to coffee plants.

\section{ACKNOWLEDGEMENTS}

The authors would like to thank CAPES, FAPEMIG, CNPq and EMBRAPA, for supporting this study.

\section{REFERENCES}

BURKE, I. C. et al. A seedling assay to screen aryloxyphenoxypropionic acid and cyclohexanedione resistance in johnsongrass (Sorghum halepense). Weed Technology, v.20, n.4, p.950-955, 2006.

CAIXETA, G. Z. T. et al. Gerenciamento como forma de garantir a competitividade da cafeicultura. Informe Agropecuário, v. 29, n. 247, p. 14-23, 2008.

CARVALHO, F, P. et al. Sensibilidade de plantas de café micorrizadas à herbicidas. Revista Brasileira de Herbicidas, v.13, n. 2, p. 134-142, 2014.

CONAB. $2^{\circ}$ levantamento da safra de café 2017/ 2018. Brasília, 2018. Disponível em: https://www.conab.gov. br/info-agro/safras/cafe. Acesso em: jul. 2018.

CUNHA, J. L. X. L. et al. Comparação de métodos de área foliar em Chrysobalanus icaco L. Agropecuária Científica no Semiárido, v. 6, n. 3, p. 22-27, 2010.
EUROPEAN WEED RESEARCH COUNCIL (EWRC). Report of the $3^{\text {rd }}$ and $4^{\text {th }}$ meetings of EWRC. Committee of methods in weed research. Weed Research, v. 4, p. 88, 1964.

FERREIRA, D. F. Sisvar: a computer statistical analysis system. Ciência e Agrotecnologia, v. 35, n. 6, p. 1039-1042, 2011.

FIALHO, C. M. T., et al. Interferência de plantas daninhas sobre o crescimento inicial de Coffea arabica L. Planta Daninha, v.29, n.1, p. 137-147, 2011.

GANDOLFO, M. A.; et al. Effect of working pressure at different spray nozzles on drift quantification in wind tunnel. Engenharia Agrícola, v.34, n.1, 2014.

INTERNATIONAL COFFEE ORGANIZATION. Total production by all exporting countries. Available on: $\quad<$ http://www.ico.org/prices/po-production.pdf $>$. Access in: 21 Nov. 2018.

JORGE, L. A. C. \& SILVA, D. J. C. B. SAFIRA: Manual de utilização. São Carlos: Embrapa CPDIA, 2010. 29p.

LIU, L. C., et al. Fluazifop and quizalofop, grass herbicides, in coffee. Journal of Agriculture of the University of Puerto Rico, v.77, n.3-4, p.201-205, 1993.

LORENZI, H. Manual de Identificação e controle de plantas daninhas. $7^{\text {a }} \mathrm{Ed}$. Nova Odessa $-\mathrm{SP}$. Instituto Plantarum, 2014. 384p.

MATIELlO, J. B. et al. Cultura de Café no Brasil: manual de recomendações. Rio de Janeiro: MAPA/ PROCAFE, 2010. 542 p.

O'BRIEN, T. P.; et al. Polychromatic staining of plant cell walls by toluidine blue O. Protoplasma, v. 59, n. 2, p. 368-373, 1964.

OLIVEIRA, C. M., et al. Economic impact of exotic insect pests in Brazilian agriculture. Journal of Applied Entomology, v. 137, n. 1-2, p. 1-15, 2013.

RODRIGUES, B. N. \& ALMEIDA, F. S. Guia de herbicidas. $7^{\mathrm{a}}$ ed., Londrina, 2018. 697p.

RONCHI, C. P. et al. Acúmulo de nutrientes pelo cafeeiro sob interferência de plantas daninhas. Planta Daninha, v. 21, n. 2, p. 219-227, 2003. 
SASAKI, Y.; et al. The compartmentation of acetylcoenzyme A carboxylase in plants. Plant Physiology, v.108, n.2, p.445-449, 1995.

SEGATTO, F. B.; et al. Técnica para o estudo da anatomia da epiderme foliar de batata. Ciência Rural, v.34, n.5, p.1597-1601, 2004.

SILVA, H., et al. Relationships between leaf anatomy, morphology, and water use efficiency in Aloe vera (L) Burm f. as a function of water availability. Revista chilena de história natural, v. 87, n. 1, p. 13, 2014.
SILVA, L. G., et al. Sintomas de fitotoxicidade e crescimento de mudas de café submetidas aos herbicidas inibidores da PROTOX. Coffee Science, v.12, n.3, 2017.

YAMASHITA, O. M., et al. Tolerância de mudas de café Conillon (Coffea canephora P.) a herbicidas aplicados em pós-emergência. Scientia Agraria, v. 10, n.2, p.169-174, 2009.

YAN, J., et al. High photosynthetic rate and water use efficiency of Miscanthus lutarioriparius characterize an energy crop in the semiarid temperate region. Gcb Bioenergy, v. 7, n. 2, p. 207-218, 2015. 